UDC 343

DOI https://doi.org/10.32838/2707-0581/2019.6/26

Rohatynska N.Z.

Ternopil National Economic University

\title{
CRIMINALITY IN FOREIGN ECONOMIC ACTIVITY
}

The article analyzed crime in foreign economic activity. It is noted that illegal movement of goods across the customs border of Ukraine is directly related to tax evasion, taking into account that the corresponding goods and transport transactions are further used in case of illegal overestimation of gross expenses and tax credit, as well as underestimation of gross revenues and tax liabilities. Attention is drawn to the fact that the criminal offence is preceded by an administrative offence, namely, the commission of an administrative offence - violation of customs rules under article 485 of the Customs Code of Ukraine precedes the commission of a criminal offence of tax evasion (fees, mandatory payments), the liability for which is provided for in article 212 of the Criminal Code of Ukraine. Attention is drawn to the fact that detection and suppression of violations of the legislation of Ukraine on issues of state customs case, detection of criminal offences in customs and tax sphere, prevention and suppression of channels of illegal movement of goods across the customs border of Ukraine, the State Fiscal Service of Ukraine since 2015 has started and organized the corresponding work of units of the tax police of the SFS and its territorial bodies. It is noted that the customs value of goods imported into Ukraine «under contract» is significantly lower than the average market prices - accordingly, it is charged less amounts of customs payments. To resolve this issue, which will allow to increase the level of payment of taxes in the real level, it is offered to enter, first, continuous monitoring risky externally the foreign economic operations of subjects of foreign economic activity with the enterprises, Registered in offshore zones and countries with preferential taxation, and their comprehensive development and make changes in the methodology for determining the customs value of imported goods, Including through the updating of existing and the conclusion of new memorandums of understanding and the cooperation of SFS with industry associations and leading importers of goods.

Key words: foreign economic activity, criminality, tax evasion, illegal movement of goods across the customs border of Ukraine.

Statement of a problem. In the foreign economic activity of Ukraine, trends are common when, in addition to the real sector of the economy, exports and imports of goods are carried out by so-called "risk" entities registered in different regions of Ukraine, in whose activities there are signs of fictitious. In particular, it is when the economic entity in one person has the founder, director and chief accountant, there are no fixed assets, the number of employees is not more than one person. Some of such enterprises are not value added tax (VAT) payers, do not file reports, do not return foreign exchange revenues, as they carry out their activities only for a short time. The use of such enterprises in the conduct of economic entities of foreign economic activity is primarily related to the purpose of understatement of the object of taxation and, accordingly, non-payment of taxes to the budget [1].

Article 212 of the Criminal Code provides for a criminal offence - intentional evasion of taxes and fees (Mandatory payments) included in the system of taxation, introduced in accordance with the pro- cedure established by law, Committed by an official of an enterprise, institution, organization, regardless of the form of ownership or person, Engaged in business activities without the formation of a legal entity, or any other person, Which is obliged to pay them if these acts have resulted in the actual non-receipt of substantial, large and particularly large amounts of funds into budgets or public funds [2].

Analysis of the last researches and publications. Some aspects of offenses in the sphere of customs regulation of foreign economic activity are reflected in the researches of E.V. Dodina, O.P. Grebelnik, V.P. Pashka, S.S. Tereshchenko, M.T. Belukhi and others.

Purpose of scientific research - is the systematization of types of offenses in the sphere of customs regulation of foreign economic activity and determination of the reasons for their commission.

Statement of the main material. Illegal movement of goods across the customs border of Ukraine is directly related to tax evasion, taking into account that the corresponding goods and transport transactions are 
further used in case of illegal overestimation of gross expenses and tax credit, as well as underestimation of gross revenues and tax liabilities. Thus, the criminal offence is preceded by an administrative offence, namely, the commission of an administrative offence violation of customs rules under article 485 of the Customs Code of Ukraine precedes the commission of a criminal offence of tax evasion (fees, mandatory payments), for which responsibility is provided for in article 212 of the Criminal Code of Ukraine [1].

Risks of such offences include understatement/ overstatement of the customs value of goods; Declaration of goods according to the wrong code Ukrainian Classification of Goods of Foreign Economic Activity (UCG FEA) of movement of goods with concealment from customs control (underweight and quantity of goods, partial non-declaration of goods); Declaring false information about the country of origin of goods; Movement of goods outside checkpoints (including through the "green section" of the border), as well as with concealment from customs control, carrying out foreign economic transactions with controlled economic entities - non-residents registered in offshore zones; Movement of commercial goods by shredding into small batches; Movement of commercial goods under the guise of humanitarian assistance for further implementation [1].

Taking into account qualitative and quantitative characteristics, place and method of production and transportation, the following groups of goods are more involved in risk operations: when importing petrol, lubricants, means of ground transport, fish and seafood; For export - ferrous metals, cereals, fats and oils, [2]. In addition, the illegal movement across the customs border of highly liquid goods such as walnut, amber and cars has become massive. Let's take a look at these questions.

Amber is a mineral of a class of organic compounds, a fossil resin of coniferous trees in the mostly paleogene period [3]. Amber is widely used to make all kinds of jewelry and household items. It is highly valued in China, Europe and Arab countries. At the same time, the complicated legal regulation of the use of subsoil, the complexity of the procedure for obtaining a special permit for the use of subsoil, the need to obtain a number of permits, solutions for the start of mining have long discouraged potential investors from investing in the development of amber deposits in Ukraine. At the same time, in the world market of precious stones, amber prices are growing exponentially [4].

Today Ukraine officially produces 2 tons of amber per year. Illegally, according to market participants - from 50 to 250 tons. By indirect signs, using open information from Poland, China and Russia, it is possible to confirm production of 30-80 tons of Ukrainian stone. Technically speaking, Ukraine supplies to the world market somewhere 5-8\% of world production. The average price of produced in Ukraine and sold kilogram will be 600-700 US dollars. 80 tons of stone produced in Ukraine we multiply by the maximum 700 US dollars per kilogram and receive 56 million. USD - approximate volume of local production market per year [5].

The next interesting type of goods that are subject to customs violations, and in turn participate in tax evasion by economic entities, are walnut nuts. Every year thousands of tons of walnuts are exported from Ukraine, which are in great demand around the world and are used in various confectionery industries from Europe to the Middle East. Abuse accompanies this business throughout the chain, and results in multimillion-dollar amounts of extra profits and under expenditure taxes. At the same time, Ukraine has its own specifics of growing and harvesting "walnut" they are mainly grown on private farms and country plots (about 90\%), which in the future are bought by large wholesalers. At the same time, for the purpose of non-payment of taxes in the budget, in the Village Councils and country cooperatives the fictitious certificates of origin of nuts issued most often on the dyed people in whom about 100 tons of nuts register are made out. This illegal legalization of the goods allows not to pay to the budget about 100 million. UAH tax on income of individuals annually [6].

We will give an approximate algorithm of detection of risky foreign economic operations by control bodies.

1. In order to determine the subjects of foreign economic activity that fall under the risk criteria, the Information System "Tax Block" establishes the registration data of the subject, in particular: Name, identification code, legal address, phones, director, accountant, founders, number of employees, accounts in banking institutions, branches, subsidiaries, production profile, industry affiliation, distribution of property rights (nominal owners, real owners (legal entities, individuals), their contact details, in turns, relations with representatives of authorities and politicians, attitude to groups of influence, financial-industrial groups, criminal groups.

2. Verification of the legitimacy of officials without interference in the activities of the enterprise through interviews with their consent.

3. Check the location of the enterprise at the tax address; determine the possibility of carrying out 
economic operations by the subject of foreign economic activity (availability of office, warehouse premises, production facilities, real number of workers).

4. Analysis of foreign economic activity of the VED subject using the Automated System of Customs Clearance (ASCC) "Inspector-2006", namely:

- establishment of the number of foreign economic transactions carried out, their total customs value, the number of customs payments paid, the total weight in terms of each product;

- identification of non-residents and full verification through official means;

- identification of commodity groups exported / imported by the Foreign Economic Activity (FEA) entity, their analysis according to the requirements of the Ukrainian Classification of Goods of External Economic Activity;

- studying of cargo and customs declarations (CCD) and the package of documents (the contract, the specification to the contract, an invoice, the country of origin, a trademark, the international commodity-transport consignment note (CMR), the book of the international road transport (Carnet TIR), certificates, permissions, licenses, the contract on declaring, etc.);

- analysis of prices (using the information resources of the State enterprise "State Information and Analytical Center for Monitoring External Commodity Markets", commodity exchanges, etc.);

- identification of the carrier company (name, place of registration, vehicles);

- identification of declarations that perform customs clearance and their contact details, customs offices at the border, customs posts where customs clearance is carried out;

- establishment of a banking institution through which funds are transferred for exported goods.

5. Analysis of exported/imported goods, in particular:

- determination of the composition of the product, scope of application, characteristics, analysis of the commodity code according to (UCG FEA), rate of duty, necessary documents of non-tariff regulation (certificates, permits, conclusions, technical conditions, State standard, etc.);

- examination of goods using the Internet (identification of characteristics, destination, retail prices, trademark, search of official representatives of goods in the territory of Ukraine, establishment of contact with them - obtaining advice);

- comparison of goods with previously issued or similar goods (by code, trademark, manufacturer), analysis of its cargo declarations.
6. Development of chain of supply of goods from producer to exporter and further to non-resident (analysis of financial and economic activity of enterprises, value of goods at customs clearance and at sale, so-called "twists" at purchase and export of goods are possible, etc.).

7. Determination of the circle of persons to whom a risky enterprise is controlled, establishment of a full circle of affiliates and controlled economic entities.

8. In case of signs of criminal activity in the actions of these persons - carrying out a complex of operational and search measures.

9. In the event of the detection of signs of the commission of an offence, a decision is taken in accordance with article 214 of the Code of Criminal Procedure on the registration of criminal proceedings in the Unified Register of Pre-Trial Investigations, the conduct of preliminary investigations on it, the conduct of measures to compensate the State for the damage caused and the referral of criminal proceedings to the court.

Let's look at typical types of offences in the customs sphere.

Let's look at the individual risk activities in detail.

First of all, it is carrying out risky export operations with "walnut" goods.

Economic entities - exporters of "walnut" goods (code of UCG FEA 0802310000, 0802320000) purchase nuts from the population for cash, and in violation of the requirements of articles 168,170 of the Tax Code of Ukraine tax on the income of individuals is not paid to the budget. Fictitious enterprises and controlled natural persons-entrepreneurs who are on a simplified tax system can be used to legalize nuts purchased from the population.

On the basis of the documents received from the taxpayer, the Chamber of Commerce and Industry prepares a conclusion on the origin of the goods "walnut", which is duly registered and is the main document on the basis of which the Certificate of Origin of the goods is subsequently issued. The data on the origin of the goods and the basis for their receipt are entered with false information about the name of the supplier of nuts (legal or natural person), the registration number and the date of the expenditure consignment note on the basis of which the export storage system purchased the goods, and in case of purchase of nuts on the market, information about the owner of the market, its name, location and number and date of the certificate issued by the market administration are entered.

Entrepreneurs who sell highly liquid goods through the Internet, on markets or in the retail trading 
network, when ordering a lot of goods abroad, in order to minimize the payment of customs payments, apply to the organizers of the illegal scheme, the essence of which is as follows. In order to avoid payment of customs payments during import operations, the attackers use the provisions of article 287 of the Customs Code of Ukraine, which defines that goods imported (transferred) into the customs territory of Ukraine, defined in accordance with the Law of Ukraine "On Humanitarian Assistance" by the Commission on Humanitarian Assistance under the Cabinet of Ministers of Ukraine humanitarian assistance, are exempt from taxation of import duty [7].

In order to implement the scheme, the organizers create or use already created pseudo-charitable organizations, on behalf of which they submit to the Ministry of Social Policy of Ukraine an application for recognition of goods with humanitarian assistance, to which false documents are attached, or those containing false information.

However, due to the short time frame for consideration by the working group under the Ministry of Social Policy of Ukraine of such applications (5 days from the date of receipt of documents), it is almost impossible to establish the inaccuracy of the documents provided. Therefore, mainly, the Ministry of Social Policy of Ukraine issues orders on recognition of goods declared on behalf of pseudo-charitable organizations, humanitarian assistance. This order is published on the official website of the Ministry of Social Policy of Ukraine and is sent to interested executive bodies. After that, the attackers submit an additional (main) customs declaration to the corresponding SFS customs office and distribute the goods without paying customs payments. The goods are then delivered to customers who sell them via the Internet, markets and retail stores, mainly for cash, and the organizers of the scheme submit false information to local authorities about the target direction of humanitarian assistance.

This illegal mechanism is used to evade customs payments when importing both highly liquid goods and used goods - the so-called "Second-hand".

Evasion of customs payments in case of import into the customs territory of Ukraine of used cars by understatement of customs value.

Evasion of customs payments when importing goods with a view to their further sale by grinding into small batches.

Until 1 January 2018, Ukrainian customs legislation provided for a simplified procedure for the movement (transfer) across the customs border of Ukraine of goods transferred by citizens for personal, family and other needs unrelated to the conduct of business activities (article 364, paragraph 1, of the Customs Code of Ukraine). This norm was used by citizens to import goods into the territory of Ukraine for commercial purposes without paying customs payments. In addition, the receipt of virtually unreported products makes it possible to evade other taxes and fees payable in the conduct of business activities, and also damages the State budget of Ukraine.

It should be noted positively the work of the legislator, by amending the Tax Code of Ukraine made this scheme economically unfavorable. On December 7, 2018 the Supreme Council of Ukraine made amendments to which it limited duty-free import of goods through border, in particular in Article 191 of the Tax Code of Ukraine ten times, namely "in case of import to the customs territory of Ukraine in hand luggage and/or in the accompanied baggage goods (Except for sub-excise goods and personal effects), the total invoice value of which does not exceed the equivalent of 500 euros and the total weight of which does not exceed $50 \mathrm{~kg}$, Through other than open for air traffic, crossing points across the state border of Ukraine physical combat, Who was absent in Ukraine for less than 24 hours or entering Ukraine more often than once within 72 hours, The tax base is a part of the total invoice value of such goods, exceeds the equivalent of 50 euros, taking into account the duty payable" [8].

That is, from January 1, 2018 it is possible to bring goods worth not more than 50 euros and weighing not more than 50 kilograms once every three days to the territory of Ukraine free of charge. At the same time, the citizen must be abroad for more than 24 hours, that is, it is not possible to return with the goods on the same day. In addition, you can now buy goods abroad via the Internet and receive them by mail duty-free only three parcels per month for the amount of 150 euros each, the fourth will already go with $20 \%$ VAT.

The next type is tax evasion by transposing goods and material assets when moving across the customs border of Ukraine.

The essence of the scheme is this. The documents submitted for customs clearance contain unreliable information about the physical properties of the inventory that is imported. In addition, one customs declaration declares goods with a low tax burden, which in weight dimension account for more than $50 \%$ of the total weight on the customs declaration, and goods with a much larger tax burden and a high customs value of significantly smaller volumes.

For example, clothing of the appropriate colour, model and profile, the customs value of which is a 
certain amount, and in fact items are imported under this article but with completely different physical characteristics and significantly higher than the cost, are declared under the corresponding article.

Goods are sold for cash to economic entities with signs of "fictitious", which testifies to the formation of a scheme tax credit to third parties. In the future, economic entities with signs of "fictitious" sell these goods to enterprises of the real sector of the economy.

The next scheme - evasion of payment of customs payments when importing into the customs territory of Ukraine highly liquid goods outside customs control with their subsequent replacement with declared ones, having a low tax burden.

It's the following. After the goods arrive at the crossing point across the state border of Ukraine to the internal customs office, the attackers provide a preliminary customs declaration and shipping documents with knowingly false information about the nomenclature, weight and quantitative characteristics of the goods. As a rule, goods with low customs load are specified, and in fact more valuable goods (household appliances, brand clothes, electronic equipment, etc.) are carried out. After customs procedures at the crossing point without actual inspection of the goods, the vehicle does not go to the customs office of destination, but is sent to the rented/own warehouse, which is usually located in a closed protected area and has the possibility of entering dimensional vehicles and carrying out loading unloading. Products with low tax burden specified in the customs declaration are placed in advance to such premises. After the car enters the warehouse, the participants of the illegal scheme perform unauthorized access to the goods (by damaging seals or using the technological features of the tented cars), unassigned highly liquid goods are unloaded and declared goods of the same weight are loaded into its place. After that, the car follows to the customs office of destination, where it completes the customs clearance. In the future, the smuggled goods are sent to the customers, and the substitute goods are returned to the warehouse where they were loaded to repeat the cycle of the specified scheme.

Evasion of customs payments when highly liquid goods (worth more than 1000 euros) are transferred to the customs territory of Ukraine through checkpoints open for air traffic in hand luggage outside customs control, by non-declaration.

This scheme is used by the owners of retail stores engaged in sales activities of famous world brands of small size (Louis Vuitton, Gucci, Chanel, Valentino, Dolce \& Gabbana, Dior, Rolex, etc.). The organizer of the scheme searches abroad for the necessary goods, on which the courier is sent. The latter plane follows in selected countries, where it buys brand clothes, shoes, accessories and jewelry worth at least 20-30 thousand euro. When returning to the territory of Ukraine, the courier chooses a form of customs control on the channel "green corridor", intended for citizens moving goods across the customs border of Ukraine in volumes not subject to taxation by customs payments and written declaration (worth up to 1000 euros), which leads to evasion of payment of customs payments.

Tax evasion scheme and non-return of foreign currency revenue through the use of fictitious firms.

In addition to these, other methods and methods may be used to evade the payment of taxes by subjects of foreign economic activity.

In order to detect and suppress violations of Ukrainian legislation on State customs matters, detect criminal offences in the customs and tax spheres, prevent and suppress channels of illegal movement of goods across the customs border of Ukraine, the State Fiscal Service of Ukraine has organized the relevant work of the tax police units of the DFS and its territorial bodies since 2015 [9].

By 2015-2017, the tax police achieved significant results in exposing criminal offences in the customs sphere.

In 2015, 343 criminal proceedings in the customs sphere were entered into the Unified Register of Pretrial Investigations, 228 of which were under article 212 of the Criminal Code of Ukraine, under which 177700000 UAN were reimbursed to the State budget. Losses caused. In order to prevent illegal formation of tax credit by enterprises of the real sector of the economy, 698 guidelines on possible violations of customs rules were sent to the customs offices of the SFS. 427 protocols on customs violations have been drawn up for a total of 117900000 UAN fines. As a result of the review of administrative proceedings under the protocols, 227 orders were issued to impose administrative penalties (fines) in the amount of 51300000 UAN, of which 11700000 is collected in the budget UAN, Confiscated property in the amount of 64 million UAN [10].

In 2016, 327 criminal proceedings were registered in the Unified register of pre-trial investigations, 165 of which were under article 212 of the Criminal Code of Ukraine, during the investigation of which 274700000 UAN were reimbursed to the State budget. 699 guidelines on possible violations of customs regulations have been provided to SFS customs offices. Based on the results of the guidelines, 883 protocols on violation of customs regulations by 
FEA entities have been drawn up by customs offices. Under the protocols drawn up, fines in the amount of 75100000 UAN, were imposed on violators of customs regulations, From which 9100000 UAN was collected in the budget, Confiscated inventory in the amount of 54200000 UAN. [11].

In 2017, 324 criminal proceedings were registered in the Unified register of pre-trial investigations, 128 of which were under article 212 of the Criminal Code of Ukraine, during the investigation of which 390900000 UAN losses were reimbursed to the State budget. The SFS customs offices were provided with 805 guidelines on possible violations of customs regulations. On the basis of the results of the guidelines, 550 protocols on violation of customs rules by FEA entities have been drawn up by customs. Under the protocols drawn up, fines in the amount of 215400000 UAN, were imposed on violators of customs regulations, from which 16600000 UAN was recovered to the budget, confiscated inventory in the amount of 47200000 UAN [12].

In the course of activities to expose the facts of tax evasion by subjects of foreign economic activity, the tax police have established that individual organized groups are developing and implementing various criminal schemes, namely, minimizing customs payments during import; Tax evasion and non-return of foreign exchange revenues from exports. To implement these schemes, economic entities with signs of fictitious are created and used, in addition, controlled enterprises - non-residents - are involved in them. Such groups received the conditional name "Customs payment minimization centers" [13].

According to us, it is possible to provide such a formulation of this concept: The center of minimization of customs payments is a steady organized group of persons with accurate differentiation of duties of its participants and complex organizational structure which activity is directed to minimization of customs payments at customs registration of inventory items.

The Customs Payment Minimization Center may include both natural and legal persons.

At the same time, legal entities are: brokerage firms, "transit", "fictitious" economic entities, enterprises of the real sector of the economy - customers of services to minimize customs payments [1].

Natural persons who are part of the Customs Payment Minimization Center form an organized group that directly performs illegal acts. These may include:

1. Organizer (co-organizer) - creates and maintains the operation of the Customs Payment Minimization Center, has extensive corrupt connections at customs offices and other authorities.
2. Accountant - performs functions on document processing, preparation and presentation of tax reports, controls bank accounts of "transit" and "fictitious" economic entities.

3. Customs broker - performs functions on registration and submission to customs authorities of documents of customs clearance, as a rule, takes direct part in production of forged documents.

4. Front persons are natural persons (including non-residents) on whom "fictitious" or "transit" enterprises are registered for remuneration or on a permanent reimbursable basis.

5. Courier - follows the instructions of the organizer, accountant and broker [1].

The activities of such centres for the minimization of customs payments in modern conditions are a serious challenge to the sphere of public administration in the customs sphere, they exist in most schemes aimed at tax evasion applied by subjects of foreign economic activity and require considerable attention of law enforcement agencies.

Now we will consider problematic issues in the organization of the work of the supervisory bodies in the direction of exposing offences in the customs sphere.

First, it is the lack of a qualitative operational component in the organization of the work of the regional units of the tax militia. In a more in-depth study of the materials of the carried out implementations with regard to the subjects of the FEA, there is a tendency to bring to justice the heads of enterprises carrying out illegal foreign economic operations. At the same time, the issue of documenting (on operational and search materials and within the framework of tacit investigative (search) actions) and bringing to justice the true organizers of these illegal schemes, as well as persons who contribute to their implementation (in particular, employees of control bodies, customs brokers, etc.) remains outside the field of view of operational workers and investigators.

One of the main loopholes of dishonest economic entities is their import operations with commodity values, the customs value of which is significantly lower than the average market price. Its essence is that in the course of import operations, economic entities indicate in contracts that are provided to Customs the value of imported goods is significantly lower than the average market price for them in Ukraine. In the vast majority of cases, these contracts are concluded with non-residents registered in offshore zones and countries with preferential taxation. When determining customs value customs officers refer to Chapter 9 of the Customs code of 
Ukraine according to which the customs value of the goods imported in the Import mode is defined by two methods, first of which is the basic and is called "at the price of the contract (contract) concerning goods, are imported". Under the secondary method, the customs value is determined by the price of the agreement on identical goods; at the price of the contract of rather similar (similar) goods; On the basis of subtraction of value; Based on value addition (calculated value). This method is not widely used at Customs.

Conclusions. Thus, the customs value of goods imported into Ukraine "under contract" is significantly lower than the average market price - accord- ingly, it is charged less amounts of customs payments.

In our opinion, in order to resolve this issue, which will increase the level of payment of taxes in the real level, First, it is necessary to introduce constant monitoring of risky foreign economic operations of FEA entities with enterprises, Registered in offshore zones and countries with preferential taxation, and their comprehensive development and make changes in the methodology for determining the customs value of imported goods, Including by updating existing and concluding new memorandums of understanding and cooperation of SFS with relevant Associations and leading importers of goods.

\section{References:}

1. Соломенко Г.В. «Юридична кваліфікація діянь щодо ухилення від оподаткування суб'єктами зовнішньоекономічної діяльності в Україні: проблеми здійснення та шляхи їхнього вирішення» (2017) 1(2) Право і суспільство. С. 226.

2. Кримінальний кодекс України від 05.04.2001 № 2341-III. Відомості Верховної Ради України. 2001. № 25-26. ст. 131.

3. Прохоров А.М. (ред). Большая советская энциклопедия (Экслибрис 1978) т 30.

4. Соломенко Г.В. «Предметы нарушений таможенных правил» (2016) 2/2. Legea si viata. С. 144.

5. Тутов С. «Кто ответит за янтарь» Общественно-правовой портал «Ракурс» (Київ, 20 серпень 2015). URL: http://racurs.ua/912-yantar-kto-otvetit (дата звернення 25.05.2018).

6. Соломенко Г.В. Порушення митних правил як спосіб ухилення від оподаткування. Міжнародна науково-практична конференція «Юридичні наукові дискусії як фактор сталого розвитку правової доктрини та законодавства». Центр правових наукових досліджень, Київ 8-9 квітня 2016.

7. Про гуманітарну допомогу: Закон України від 22.10.1999 №1192-XIV. Відомості Верховної Ради України. 1999. № 51, ст.451.

8. Податковий кодекс України від 02.12.2010 № 2755-VI. Відомості Верховної Ради України. 2011. № 13-14, № 15-16, № 17, ст.112.

9. Про Державну фіскальну службу України: Постанова Кабінету Міністрів України від 21.05.2014 № 236. Офіційний вісник Украӥни. 2014. № 55, стаття 1507.

10. Звіт про виконання Плану роботи ДФС України на 2015 рік, затверджений 19.01.2016: URL: http://sfs.gov.ua/data/files/131201.pdf (дата звернення 10.07.2017).

11. Звіт про виконання Плану роботи ДФС України на 2016 рік, затверджений 16.02.2017. URL: http://sfs.gov.ua/data/files/199244.pdf (дата звернення 10.07.2017).

12. Звіт про виконання Плану роботи ДФС України на 2017 рік, затверджений 20.02.2018. URL: http://sfs.gov.ua/data/files/223549.PDF (дата звернення 06.03.2018).

13. Звіт про виконання Плану роботи ДФС України на перше півріччя 2016 року, затверджений 17.08.2016, п.5.3. URL: http://sfs.gov.ua/data/files/173587.pdf (дата звернення 10.07.2017).

\section{Рогатинська Н.3. ЗЛОЧИННІСТЬ У ЗОВНІШНЬОЕКОНОМІЧНІЙ ДІЯЛЬНОСТІ}

У статті проаналізовано злочинність у зовнішньоекономічній діяльності. Зазначено, що незаконне переміщення товарів через митний кордон Украӥни безпосередньо пов'язане з ухиленням від оподаткування, враховуючи, що відповідні товарно-транспортні операчї у подальшому використовуються під час неправомірного завищення валових витрат і податкового кредиту, а також заниження валових доходів та податкових зобов'язань. Звернено увагу на те, що кримінальному делікту передує адміністративний, а саме: вчинення адміністративного правопорушення - порушення митних правил за статтею 485 Митного кодексу Украӥни передує вчиненню кримінального правопорушення щъодо ухилення від сплати податків (зборів, обов'язкових платежів), відповідальність за яке передбачено статтею 212 Кримінального кодексу України. Звернено увагу на те, щчо виявлення та припинення порушень законодавства України з питань державної митної справи, виявлення кримінальних правопорушень у митній та податковій сферах, упередження та припинення каналів незаконного переміщення товарів через митний кордон України, Державною фіскальною службою 
України з 2015 року розпочато та організовано відповідну роботу підрозділів податкової мілічії ДФС та ї̈ територіальних органів. Зазначено, щцо митна вартість товару, який ввозиться в Украйну «за контрактом», значно нижча за середньоринкові ціни, відповідно, з неї стягуються менші суми митних платежів. Для врегулювання зазначеного питання запропоновано: запровадити постійний моніторинг ризикових зовнішньоекономічних операцій суб'єктів ЗЕД з підприємствами, зареєстрованими в офшорних зонах та країнах з пільговим оподаткуванням; внести зміни до методології визначення митної вартості імпортованого товару, у тому числі шляхом актуалізації наявних та укладання нових Меморандумів про взаєморозуміння; активно співпраџювати із відповідними Асоџіаціями та провідними імпортерами товарів.

Ключові слова: зовнішньоекономічна діяльність, злочинність, ухилення від сплати податків, незаконне переміщення товарів через митний кордон України. 